\title{
Preventing Dental Caries in Children : Indian Scenario
}

\section{Gupta $A,{ }^{1}$ Marya $\mathrm{CM},{ }^{2}$ Dahiya $\mathrm{V},{ }^{3}$ Bhatia $\mathrm{HP}^{4}{ }^{4}$ Dhingra $\mathrm{S}^{2}$}

${ }^{1}$ Department of Pedodontics

Desh Bhagat Dental College \& Hospital

Muktsar, Punjab, INDIA

\begin{abstract}
The prevalence of dental caries in developing countries like India is increasing to an alarming level in contrast to developed countries where it has decreased because of variety of preventive measures at the community and individual level. There is no State or Centre funded programs for prevention of dental diseases in India.

The present review enlists the targeted prevention of dental caries in permanent teeth of 6 to 16 years old children presenting for dental care.
\end{abstract}

${ }^{2}$ Department of Public Health Dentistry

${ }^{3}$ Department of Conservative Dentistry and Endodontics

Faridabad, Haryana ,INDIA

\section{KEY WORDS}

Children, Dental caries, Fluoride, Prevalence, Prevention.

\section{Corresponding Author}

Charu Mohan Marya

Department of Public Health Dentistry

Sudha Rustagi College of Dental Sciences \&Research

Faridabad, Haryana ,INDIA

Email: maryacm@yahoo.co.uk

Citation

Gupta A, Marya CM, Dahiya V, Bhatia HP, Dhingra S.Preventing Dental Caries in Children : Indian Scenario. Kathmandu Univ Med J 2012;37(1):77-82.

\section{INTRODUCTION}

Oral and Dental Health have improved tremendously over the last century in the developed countries, but the prevalence of Dental caries in the developing countries like India remains a significant clinical problem..$^{1-4}$

There also appears to be considerable clinical variation in the type of care currently being provided. This may reflect a degree of uncertainty as to which treatments are most useful, who would benefit from treatment and which treatments will achieve cost effective health gain. There are, however, proven professionally and self applied preventive techniques which can be targeted to help those with the greatest need.

Dental caries is a preventable disease of the mineralized tissues of the teeth with a multi-factorial etiology related to the interactions over time between tooth substance and certain micro organisms and dietary carbohydrates producing plaque acids.

There are wide ranges of overlapping factors to consider when assessing an individuals degree of risk from this multi factorial disease. The following factors are considered when assessing caries risk:

- $\quad$ Clinical evidence of previous disease.

Dietary habits, especially frequency of sugary food and drinks consumption.

Social history, especially socio-economic status. 


\section{- $\quad$ Use of Fluoride \\ - Plaque Control \\ - Saliva \\ - Medical History}

The goal of dental health education is to establish good oral hygiene and dietary habits. The establishment of needs related oral hygiene habits require long lasting motivation. The most important motivational factor is a feeling of individual responsibility based on self diagnosis and behavioral principles. ${ }^{5}$

There is also increased consumption of sugary soft drinks, refined carbohydrates in the form of readymade chips and other readily available products among children, teenagers and even in adults. There is a general lack of awareness about the healthy dietary habits.

Lack of regular dental checkups limited the professionally applied preventive measures like professional topical fluoride application and use of pit and fissure sealants in the population.For all these reasons the prevalence of dental caries in developing country like India is increasing to an alarming level.

A guideline should be formulated to provide the recommendations targeted for prevention of dental caries in permanent teeth of six to sixteen year old children. Effective targeted prevention of caries in the permanent dentition has great potential to achieve significant health gain, given that once an initial filling is placed a repetitive, costly, lifelong cycle of re-restoration occurs for many individuals. Prevention from age six is important if the first permanent molars are to be adequately protected.

The guideline should be intended for dentists working in primary dental care (general dental practitioners, community dental service), dental colleges \& hospitals. This guideline is for those children who presented for dental care.

\section{Primary Prevention of Dental Caries}

Keeping children's teeth healthy before disease occurs.

\section{[A] Behaviour Modification}

\section{(I) Dental Health Education}

TThe goal of dental health education is to establish good oral hygiene and dietary habits. The dental and allied professions have an ethical responsibility to inform patients about disease and how to prevent it.

A systematic review has demonstrated that dental health education carried out by a professional at the chair-side is more often effective than other types of oral health promotion interventions. ${ }^{6}$

The dental and allied professionals should carry out dental health education. Consistent preventive messages should be reinforced

Dental health education advice should be provided to individual patients at the chair-side as this intervention has been shown to be beneficial.

\section{(II)Oral Hygiene}

The value of tooth-brushing in caries prevention lies with the regular topical application of fluoride.

Toothpastes containing fluoride at 1000-2800 parts per million (ppm) have been shown to be effective in preventing dental caries in children aged between six and 16 years .,8 Children who brush twice a day show greater benefit than those who brush less frequently

\section{(III) Diet and Sugar Consumption}

Lowering sugar intake reduces the incidence of caries in children. ${ }^{9-12}$ A Brazilian study has shown that the incidence of approximal lesions in 12 years olds can be reduced by diet and oral hygiene training. ${ }^{13}$ Limiting the ingestion of refined carbohydrate to meal times is also widely recommended. ${ }^{14}$

The need to restrict sugary food and drink consumption to meal times only should be emphasized

\section{[B]Tooth Protection}

\section{(I) Sealants}

The use of resin pit and fissure sealants has been shown to be an effective barrier method of preventing caries in pits and fissures over a wide range of studies in recent decades. ${ }^{15}$ Improvements in dental materials have increased retention and improved technique sensitivity.

\section{Sealants should be applied and maintained in the tooth} pits / fissures.

For optimal efficiency, the sealant should be present in all affected pits and fissures. The condition of the sealant should be reviewed regularly with further coatings added as required.

\section{The condition of sealants should be reviewed at each check-up.}

Glass ionomer sealants have poorer retention than composite resin materials and their effect on caries reduction is equivocal. Therefore, glass ionomer sealants are mainly used when it is not possible to use a resin material, for example due to poor patient compliance.

Glass ionomer sealants should only be used when resin sealants are unsuitable.

Because of their high cost, the general decline in decay and differential tendencies for certain fissures to decay, sealants should be applied selectively to high risk patients and to permanent molars only, within 2-3 years after tooth eruption.

\section{(II) Fluoride Tablets}

Fluoride supplements may be considered for children 
with intractable caries risk. ${ }^{16}$ The report of the consultants in dental public health states that additional fluoride supplements (1mg F, 2.2mg NAF per day) are appropriate for high caries risk children and can be used where compliance is likely to be favourable. ${ }^{17}$

Fluoride tables (1 mg Fluoride daily) for daily sucking should be considered for children.

Ideally, tooth brushing and tablet taking should occur at different times to permit the longest possible period for topical fluoride uptake from each fluoride source.

\section{(III) Topical Varnishes/ Fluoride Solutions}

For children reliance on the home based use of fluoride toothpaste and tablets is deemed to be insufficient, professional application of a fluoride varnish help to prevent dental caries.

A study in Chandigarh, India evaluated the professional application of $2 \% \mathrm{NaF}$ solution, $1.23 \%$ acidulated phosphate fluoride solution (APF), or 2.26\% F Duraphat at six-monthly intervals for 30 months in children aged 6-12 years. The largest reduction in caries increment was seen with Duraphat. ${ }^{18}$

Correct application according to the manufacture's instruction is important. Fluoride concentrations may vary between products and only the recommended amount should be used.

\section{(IV)Chlorhexidine}

A meta-analysis of clinical studies assessing the caries preventive effects of chlorhexidine has demonstrated that chlorhexidine prophylaxis in the form of a rinse, gel or paste can achieve a substantial (average 46\%) reduction in caries irrespective of application method, frequency, caries risk, caries diagnosis, tooth surface, or fluoride regimen. ${ }^{19}$

Professional flossing four times a year with chlorhexidine gel has been shown to lead to significant reductions is approximal caires. This quick (10 minutes) and effective measure can be used to complement the use of sealants in protecting fissures. ${ }^{20}$

In one study, a chlorhexidine varnish (e.g. Cervitec, 1\%) was shown to be effective in preventing fissure caries when applied three time over nine months. ${ }^{21}$

Chlorhexidine varnish should be considered as an option for preventing caries.

\section{Secondary and Tertiary Prevention}

\section{Limiting the impact of caries at an early stage.}

Rehabilitation of the decayed teeth with further preventive care. In everyday clinical practice the distinction between secondary and tertiary prevention is unclear and they are therefore considered together in this section. Treating any carious lesions operatively will not prevent further disease and primary preventive measures must be continued

\section{Diagnosis of Dental Caries}

In order to deliver effective prevention, accurate diagnosis and monitoring of lesions over time are required.

Early diagnosis of approximal enamel lesions is important as the majority of lesions in the outer half of enamel will take at least two years to progress into dentine, and progression is not inevitable. ${ }^{22}$ With intervention, lesion progression can be slowed, arrested or even reversed. ${ }^{23-25}$ However, monitoring is important as in very caries active individuals rapid progression can be seen.

In the diagnosis of caries in children, systematic review of the evidence, supported by expert opinion, shows that posterior bitewing radiographs are in essential adjunct to clinical examination. ${ }^{26}$

A thorough clinical examination of clean, dried teeth should be carried out to assist caries diagnosis and to identify the patient's caries risk category prior to deciding whether to take a radiograph. This examination may include.

$$
\begin{aligned}
& \text { Transillumination } \\
& \text { Flossing } \\
& \text { Temporary separation of the teeth. }
\end{aligned}
$$

(e.g. with a wooden wedge or orthodontic separator).

Bitewing radiographs are recommended as an essential adjunct to a patient's first clinical examination.

The frequency of further radiographic examination should be determined by an assessment of the patient's caries risk.

Early caries detection methods should be an adjunct to clinical decision making, supporting preventive treatment planning in conjunction with caries risk assessment but not justifying premature restorative intervention. ${ }^{27}$

\section{Management of Carious Lesions}

The management of carious lesions can be divided into three caries sites:

\section{Occlusal caries \\ Approximal caries \\ Smooth surface caries.}

The patterns of caries initiation and progressions are different in each site, as are the management options.

\section{Management Of Occlusal Caries}

Once a decision has been taken to initiate operative intervention, it has been shown that sealant restoration are as effective as amalgam restorations in managing small to moderate sized fissure caries and involve less tooth destruction. ${ }^{28,29}$ However, it must be appreciated that the fissure sealant component requires maintenance. Using 


\section{GUIDELINES FOR CARIES RISK CLASSIFICATION, TREATMENT AND PREVENTION}

\begin{tabular}{|c|c|c|c|}
\hline Component of care & Low- risk patients & Moderate risk patients & High- risk patients \\
\hline \multirow[t]{5}{*}{$\begin{array}{l}\text { Clinical and radiographic findings } \\
\text { and current medical history }\end{array}$} & No clinical caries & $\begin{array}{l}\text { No more than two carious lesions } \\
\text { present or }\end{array}$ & More than two carious lesions or \\
\hline & No radiographic caries & $\begin{array}{l}\text { No more than two recent restora- } \\
\text { tions }\end{array}$ & More than two recent restorations \\
\hline & No recent rest orations $<1$ y & $\begin{array}{l}\text { Recent change in medical history/ } \\
\text { recent increase in risk factors }\end{array}$ & Patients who is xerostomic \\
\hline & $\begin{array}{l}\text { No recent changes in medical } \\
\text { history }\end{array}$ & & $\begin{array}{l}\text { Patient taking medications since } \\
\text { last recall visit that cause dry } \\
\text { mouth }\end{array}$ \\
\hline & No recent new medications & & \\
\hline \multirow[t]{4}{*}{ Initial therapy } & $\begin{array}{l}\text { Review risk factors (diet, } \\
\text { fluoride, use and medications) and } \\
\text { oral hygiene }\end{array}$ & Review of risk and oral hygiene & Review risk factors and oral hygiene \\
\hline & & $\begin{array}{l}\text { Immediately restore cavitated } \\
\text { lesions }\end{array}$ & $\begin{array}{l}\text { Immediately restore cavitated } \\
\text { lesions usng a defect specefic ap- } \\
\text { proach }\end{array}$ \\
\hline & & $\begin{array}{l}\text { Apply sealants to all at risk molars } \\
\text { and premolars }\end{array}$ & $\begin{array}{l}\text { Apply sealants to all at-risk molars } \\
\text { and premolars }\end{array}$ \\
\hline & & $\begin{array}{l}\text { Institute and monitor home } \\
\text { care(see below) }\end{array}$ & $\begin{array}{l}\text { Institute and monitor home care } \\
\text { (see below) }\end{array}$ \\
\hline \multirow[t]{3}{*}{ Home care protocols } & $\begin{array}{l}\text { Fluoride tooth paste, American } \\
\text { Dental Association approved }\end{array}$ & $\begin{array}{l}\text { Fluoride tooth paste, American } \\
\text { Dental Association approved }\end{array}$ & Presribe PreviDent 5000 plus \\
\hline & Oral hygiene flossing and brushing & Oral hygiene flossing and brushing & Oral hygiene flossing and brushing \\
\hline & & $\begin{array}{l}\text { Fluoride rinse }(\mathrm{ACT}) \text { or Fluorigard } \\
2 \mathrm{x} / \mathrm{d} \text { as per directions }\end{array}$ & $\begin{array}{l}\text { Advise the use of xylitol gum } \\
3-5 x / d \text {, especially when unable to } \\
\text { brush after meals or for patients } \\
\text { who are xerostomic }\end{array}$ \\
\hline
\end{tabular}

(adapted from Thompson VP, Kaim JM) ${ }^{28}$

composite instead of glass ionomers improves sealant retention. If amalgam is used as a filling material, any remaining fissures which are caries free should be fissure sealed in preference to extension for prevention.

If only part of the fissure system is involved in small to moderate dentine lesions with limited extension, the treatment of choice is a composite sealant restoration.

If fissure caries extends clinically into dentine, the current treatment of choice is to remove the caries and place a restoration, rather than sealing over the caries. ${ }^{30}$

However, if caries is inadvertently covered by a fissure sealant which is then well maintained, the caries is very unlikely to progress. ${ }^{31}$

If caries extends clinically into dentine, then carious dentine should be removed and the tooth restored.

For more extensive lesion still there is a wealth of evidence to support the use of well placed conventional amalgam fillings. Concerns about mercury hazards have not been generally substantiated..$^{32}$

Dental amalgam is an effective filling material which remains the treatment of choice in many clinical situations. There is no evidence that amalgam restorations are hazardous to the general health.

\section{Management of Approximal caries}

Application of fluoride can slow or arrest progression of approximal enamel lesions and therefore operative intervention is not indicated when lesions are at this stage of development. ${ }^{25}$

Preventive care (e.g. topical fluoride varnish) rather than operative care is recommended when approximal caries is confined (radiographically or visually) to enamel.

Management strategies for lesions confined to the enamel should also include:

Twice daily use of toothpaste containing at least 1000 ppm fluoride.

\section{Flossing}

Dietary advice.

For approximal lesions requiring restoration, a Class II approach should be used in preference to a tunnel preparation, which is technically very demanding and has been shown to have limited durability. ${ }^{33}$ Composite resin is suitable for the restoration of small to moderate sized (not subjected to direct occlusal loading) Class II cavities in premolar teeth. ${ }^{34}$ 


\section{Management of Smooth surface caries}

In free smooth surfaces, caries is easier to detect and manage. The management strategy is the same as that for approximal lesions confined to enamel.

Management strategies for smooth surface (non-cavitated) lesions should include:

Twice-daily use of a toothpaste containing at least 1000 ppm fluoride

\section{Plaque removal}

Dietary advice

(including the use of sugar free chewing gum, when acceptable)

\section{RE-RESTORATION}

It is common to find a range of previous restoration in high risk patients. Restorations may fail for a number of reasons, including factors associated with the material or technique used or the operator's skill. However, for children further decay is a particular problem. The margin between restoration and tooth tissue is a potential site for new decay, known as secondary or recurrent caries. More extensive lesions which continue to progress in spite of preventive care should be restored with an appropriate material depending on their degree of visibility.

However, the diagnosis of secondary caries is extremely difficult and there is a risk that large numbers of false diagnoses of secondary caries will lead to unwarranted replacement and re-replacement of fillings. Unnecessary replacement of fillings is deleterious to oral health and wastes scarce financial resources. ${ }^{35-38}$

The diagnosis of secondary caries is extremely difficult and clear evidence of involvement of active disease should be ascertained before replacing a restoration.

If only part of a restoration is judged to have failed, then consideration should be given to repairing rather than replacing it.

The present review documents effects for several interventions to prevent caries since extensive damage from caries can lead to major problems for the individual, affecting quality of life both functionally and esthetically. Good general health also includes good oral health. Hence, preventing caries is an important element in public health efforts.

\section{REFERENCES}

1. Tewari A, Chawla HS. A study of prevalence of dental caries in an urban area of India, Chandigarh. J Indian Dent Assoc 1977; 49:231237.

2. Gauba K, Tewai A, Chawla HS. Frequency distribution of children according to dental caries status in rural areas of Northern India (Punjab). J IND Dent Assoc 1986; 58:59-62.

3. Tewari A, Goyal A, Mehta K, Gauba K. Distribution of dental caries in India and south East Asia. In: Johnson NW, editors. Risk Markers for oral diseases. Dental Caries (vol.1): Markers of high and low risk groups and individuals. Cambridge Univ Press: Cambridge; 1991:33 $-61$

4. Chawla HS, Gauba K, Goyal A. Trends of Dental Caries in children of chandigarh over the last sixteen years. J Indian Dent Assoc 2000; 18: $41-45$.

5. Axelsson P, Buischi YA, Barboss MF, Karlsson R, Prado MC. The effect of a new oral hygiene training program on approximal caries in 12-15 year-old Brazilan Children. Results after three years. Fogorv Sz 1997 Apr; 90 Spec No: 37.

6. Sprod AJ, Anderson R, Treasure E. Effective oral health promotion: literature review. Cardiff: Health Promotion Wales 1996.

7. Chesters RK, Huntington E, Burchell CK, Stephen KW. Effect of oral care habits on caries in adolescents. Caries Res 1992; 26: 299-304.

8. Report of the Consultants in Dental Public Health. The use of fluoride toothpaste and fluoride supplements in Scotland, 1998.

9. Serra Majem L, Garcia Closas R, Ramon JM, ManauC, Cuenca E, Krasse B. Dietary habits and dental caries in a population of Spanish schoolchildren with low levels of caries experience. Caries Res 1993; 27: 488-494.

10. Gustaffson BE, Quensel $C E$, Lanke LS, Lundquist $C$, Grahnen $H$, Bonow BE et.al. The Vipeholm dental caries study. The effect of different levels of carbohydrate intake on caries activity in 436 individuals observed for five years. Acta Odont Scand 1954; 11: 232-364.

11. Mazengo MC, Tenuvuo J, Hausen H. Dental caries in relation to diet, saliva and cariogenic microorganisms in Tanzanians of selected age groups. Community Dent Oral Epidemiol 1996; 24: 169-174.

12. Lingstrom P, Holm AK, Mejare I. Dietary factors in the prevention of dental caries: a systematic review. Acta Odontol Scand 2003; 61:331340.

13. Axelsson P, Buischi YA, Barbosa MF, Karlsson R, Prado MC. The effect of a new oral hygiene training program on appoximal caries in 12-15-years-old Brazilian children: results after three years. Adv Dent Res 1994; 8:278-284.

14. Health Education Authority. Scientific basis of dental health education. 3rd edition. HMSO;1996.

15. Avinash, CM Marya, S Dhingra, P Gupta, S Kataria, Hind P et.al. Bhatia. Pit and Fissure Sealants: An Unused Caries Prevention Tool. J Oral Health Comm Dent 2010;4(1):1-6.

16. Riordan PJ. The place of fluoride supplements in caries prevention today. Aust Dent J1996; 41:335-342.

17. British Medical Association, Royal Pharmaceutical Society of Great Britain. British National Formulary (BNF 40) September 2000; 9.5.3: 441-442.

18. Tewari A, Chawla HS, Utreja A. Comparative evaluation of the role of $\mathrm{NaF}, \mathrm{APF}$ and Duraphat topical fluoride applications in the prevention of dental caries - a 21/2 years study. J Indian Soc Pedodont Prev Dent 1991;8: 28-35

19. Van Rijkom HM, Truin GJ, van't Hof MA. A meta-analysis of clinical studies on the caries- inhibiting effect of chlorhexidine treatment. J Dent Res 1996; 75:790-795.

20. Gisselsson H, Birkhed D, Bjorn, A-L. Effect of professional flossing with chlorhexidine gel on approximal caries in 12-15-year-old schoolchildren. Caries Res 1998; 22: 187-192. 
21. Bratthal D, Serinirach R, Rapisuwon S, Kuratana M, Luangjarmekorn V, Luksila $\mathrm{K}$, et al. A study into the prevention of fissure caries using an antimicrobial varnish. Int Dent J 1995; 45- 245-254.

22. Brabner D, Downer MC, Moles DR, Naylor MN. Initial caries attack and average progression rates in 12 year-old Isle of White children. Community Dent Health 1995; 12: 190-193.

23. Pitts NB. Regression of approximal carious lesions diagnosed from serial standardized bitewing radiographs. Caries Res 1986; 20: 85-90.

24. Petersson LG, Arthursson, L. Ostberg C, Jonsson G, Gleerup A. Caries-inhibiting effects of different modes of Duraphat varnish reapplication: a 3-yar radiographic study. Caries Res 1991; 25:70-73.

25. Seppa L, Hausen H, Tuutti H, Luoma H.Effect of a sodium fluoride varnish on the progress of initial caries lesions. Scand J Dent Res 1983; 91: 96-98.

26. Kidd EA, Pitts NB. A reappraisal of the bitewing radiograph in the diagnosis of posterior approximal caries. Br Dent J 1990; 169: 195200.

27. Andréa Ferreira Zandoná, Domenick T. Diagnostic tools for early caries detection. JADA 2006;137(12):1675-1684.

28. Van P. Thompson, James M. Kaim. Nonsurgical Treatment of Incipient and Hidden Caries. Dent Clin N Am 2005; 49: 905-921.

29. Welbury RR, Walls AW, Murray JJ, McCabe JF. The management of occlusal caries in the permanent molars. A 5 years clinical trial comparing a minimal composite with an amalgam restoration. $\mathrm{Br}$ Dent J 1990; 169:361-366.
30. Weerheijm KL, de Soet JJ, van Amerongen WE, de Graaff J.Sealing of occulasal hidden caries lesions: an alternative for curative treatment? ASDC J Delhi Child 1992: 59:263-268.

31. Mertz-Fairhurst EJ, Smith CD, Williams JE, Sherrer JD, Mackert $J R$, Richards EE, et al. Cariostatic and ultraconservative sealed restrorations: six years results. Quintessence International 1992; 23: 827-838.

32. Corbin SB, Kohn WG. The benefits and risks of dental amalgam: current findings reviewed. J Am Dent Assoc 1994; 125-381-388.

33. Strand GV, Nordbo H, Tveit AB, Espelid I, Wikstrand K, Eide GE. A 3-year clinical study of tunnel restorations. Eur J of Oral Sci 1996; 104: 384-389.

34. Lundin SA, Andersson B, Koch G, Rasmusson CG. Class II composite resin restoration: a three-year clinical study of six different posterior composites. Swed Dent J 1990;14: 105-114.

35. Mjor IA. The reasons for replacement and the age of failed restoration in general dental practice. Acta Odontol Scand 1997;55: 58-63.

36. Kidd EA, Beighton D. Prediction of secondary caries around toothcolored restorations: a clinical and microbiological study. J Dent Res 1996; 75: 1942-1946.

37. Kidd EA, Joyston- Bechal S, Beighton D.Diagnosis of secondary caries: a laboratory study. Br Dent J 1994; 176: 135-139.

38. Kidd EA, Toffenetti F, Mjor IA. Secondary caries. Int Dent J 1992; 42: 127-138. 